\title{
PERAN OTORITAS JASA KEUANGAN TERHADAP PENGAWASAN LEMBAGA KEUANGAN DI INDONESIA
}

\author{
Annisa Arifka Sari \\ Sekolah Tinggi Ilmu Ekonomi Perbankan Indonesia \\ Email: annisaarifkasari@gmail.com
}

\section{Info Artikel:}

Diterima: 12 Oktober 2019 | Disetujui: 15 Oktober 2019

| Dipublikasikan: 27 Desember 2019

\begin{abstract}
Abstrak
Penelitian ini bertujuan untuk menjelaskan peran Otoritas Jasa Keuangan sebagai lembaga independen dalam melakukan pengawasan terhadap lembaga jasa keuangan di Indonesia serta kewenangan Otoritas Jasa Keuangan yang diatur dalam Undang-Undang Nomor 21 Tahun 2011 tentang Otoritas Jasa Keuangan. Metode yang digunakan dalam penelitian ini adalah penelitian hukum normatif. Dari hasil penelitian dijelaskan bahwa Otoritas Jasa Keuangan adalah lembaga yang independen dan bebas dari campur tangan pihak lain, yang mempunyai fungsi, tugas, dan wewenang pengaturan, pengawasan, pemeriksaan, dan penyidikan terhadap lembaga jasa keuangan seperti perbankan. Dasar hukum dibentuknya Otoritas Jasa Keuangan adalah Undang-Undang Nomor 21 Tahun 2011. Secara kelembagaan, Otoritas Jasa Keuangan berada di luar pemerintah, yang dimaknai bahwa Otoritas Jasa Keuangan tidak menjadi bagian dari kekuasaan pemerintah. Otoritas Jasa Keuangan dibentuk dengan tujuan agar keseluruhan kegiatan di dalam sektor jasa keuangan terselenggara secara teratur, adil, transparan, dan akuntabel; mampu mewujudkan sistem keuangan yang tumbuh secara berkelanjutan dan stabil; serta mampu melindungi kepentingan konsumen dan masyarakat. Otoritas Jasa Keuangan bertugas tidak hanya mengatur dan mengawasi perbankan saja, tetapi juga mencakup pasar modal, perasuransian, dana pensiun, lembaga pembiayaan, serta lembaga jasa keuangan lainnya.
\end{abstract}

Kata kunci: Hukum, Otoritas Jasa Keuangan, Pengawasan Lembaga Keuangan

\section{THE ROLE OF FINANCIAL SERVICES AUTHORITY ON SUPERVISION OF FINANCIAL INSTITUTIONS IN INDONESIA}

\begin{abstract}
This research aims to explain the role of the Financial Services Authority as an independent institution in supervising financial service institutions in Indonesia as well as the authority of the Financial Services Authority as regulated in Law Number 21 of 2011 concerning the Financial Services Authority. The method used in this research is normative legal research. From the research results, it is explained that the Financial Services Authority is an independent institution and free from interference from other parties, which has the function, task and authority to regulate, supervise, examine and investigate financial service institutions such as banks. The legal basis for the establishment of the Financial Services Authority is Law Number 21 of 2011. Institutionally, the Financial Services Authority is outside the government, which means that the Financial Services Authority is not part of the government's power. The Financial Services Authority was formed with the aim that all activities in the financial services sector are carried out in an orderly, fair, transparent and accountable manner; able to realize a financial system that grows in a sustainable and stable manner; and able to protect the interests of consumers and society. The Financial Services Authority is tasked with not only regulating and supervising banking, but also covering the capital market, insurance, pension funds, financing institutions, and other financial service institutions.
\end{abstract}

Keywords: Law, Financial Services Authority, Supervision of Financial Institutions 


\section{A. PENDAHULUAN}

Otoritas Jasa Keuangan, yang disingkat OJK, merupakan lembaga negara independen yang bebas dari campur tangan pemerintah, yang memiliki kewenangan, fungsi, serta tugas dalam pengaturan, pengawasan, pemeriksaan, dan penyidikan terhadap sektor perbankan, pasar modal, perasuransian, dana pensiun, lembaga pembiayaan, dan lembaga jasa keuangan lainnya. Hal ini sebagaimana yang tertuang dalam Undang-Undang Nomor 21 Tahun 2011 tentang Otoritas Jasa Keuangan. Dibentuknya Otoritas Jasa Keuangan sebagai lembaga pengawas pada sektor keuangan merupakan amanat UndangUndang Nomor 3 Tahun 2004 tentang Perubahan atas Undang-Undang Nomor 23 Tahun 1999 tentang Bank Indonesia. Dalam undang-undang tersebut, khususnya Pasal 34 Ayat (1) dan Ayat (2), dijelaskan bahwa pengawasan terhadap bank dilakukan oleh lembaga pengawasan sektor jasa keuangan yang independen dan dibentuk oleh undang-undang. ${ }^{1}$

Secara historis, ide dibentuknya Otoritas Jasa Keuangan sudah diwacanakan pada masa pemerintahan Presiden B.J. Habibie ketika pemerintah menyusun Rancangan Undang-Undang tentang Bank Indonesia. Ide pemisahan fungsi

${ }^{1}$ Laurensius Arliman S., Lembaga-lembaga Negara Independen (Dalam Undang-Undang Dasar Negara Republik Indonesia Tahun 1945), (Yogyakarta: Deepublish, 2016), hlm. 53. pengawasan dari bank sentral ini disampaikan oleh mantan gubernur bank sentral Jerman, Helmut Schlesinger, yang pada waktu itu ditunjuk sebagai konsultan dalam penyusunan Rancangan UndangUndang tentang Bank Indonesia dengan mengambil pola bank sentral Jerman yang tidak mengawasi perbankan.

Setelah diundangkan dan disahkannya Undang-Undang Nomor 21 Tahun 2011 tentang Otoritas Jasa Keuangan, maka Otoritas Jasa Keuangan menggantikan fungsi pengawasan pada sektor jasa keuangan yang sebelumnya dipegang oleh Bank Indonesia dan Badan Pengawas Pasar Modal dan Lembaga Keuangan. ${ }^{2}$ Hal ini bertujuan agar pengawasan menjadi terintegrasi dan komprehensif. Adapun aspek-aspek independensi dari kewenangan dalam pengaturan perundang-undangan yang diatur dalam Undang-Undang Nomor 21 Tahun 2011 tentang Otoritas Jasa Keuangan tercantum dengan jelas dan tegas, yaitu Otoritas Jasa Keuangan dibentuk dan dilandasi oleh prinsip-prinsip tata kelola yang meliputi independensi, akuntabilitas, tanggung jawab, dan transparansi. Dilihat secara kelembagaan, Otoritas Jasa Keuangan merupakan lembaga independen yang dalam

\footnotetext{
${ }^{2}$ Wiwin Sri Haryani, "Independensi Otoritas Jasa Keuangan dalam Perspektif Undang-Undang Nomor 21 Tahun 2011 tentang Otoritas Jasa Keuangan”, Jurnal Legislasi Indonesia, Volume 9, Nomor 3, 2012, hlm. 10.
} 
menjalankan tugas serta kewenangannya bebas dari campur tangan pihak lain serta lembaga negara lainnya, kecuali mengenai hal-hal yang secara tegas diatur dalam Undang-Undang Nomor 21 Tahun 2011 tentang Otoritas Jasa Keuangan. Hal ini dijelaskan dalam Pasal 2 Ayat (2) UndangUndang Nomor 21 Tahun 2011 tentang Otoritas Jasa Keuangan.

Meskipun sudah dinyatakan secara jelas dan tegas dalam undang-undang bahwa Otoritas Jasa Keuangan terbebas dari campur tangan pemerintah, namun dalam praktiknya independensi Otoritas Jasa Keuangan masih diragukan dan diperdebatkan oleh beberapa pihak. Isu yang paling sering muncul mengenai Otoritas Jasa Keuangan berkaitan dengan pimpinan lembaga atau yang disebut Dewan Komisioner Otoritas Jasa Keuangan, baik dari segi komposisinya maupun dari segi proses pemilihannya. Pasal 10 Ayat (4) Undang-Undang Nomor 21 Tahun 2011 tentang Otoritas Jasa Keuangan menyebutkan bahwa komposisi Dewan Komisioner Otoritas Jasa Keuangan terdiri dari 9 orang dan 7 orang di antaranya diseleksi oleh panitia seleksi yang dibentuk melalui keputusan Presiden, sedangkan 2 orang Dewan Komisioner Otoritas Jasa Keuangan lainnya berasal dari anggota Dewan Gubernur Bank Indonesia dan pejabat Kementerian Keuangan yang golongannya setara dengan Eselon I.
Dilihat dari proses pemilihannya, dalam Pasal 11 Ayat (1) Undang-Undang Nomor 21 Tahun 2011 tentang Otoritas Jasa Keuangan disebutkan bahwa Dewan Komisioner Otoritas Jasa Keuangan dipilih oleh Dewan Perwakilan Rakyat (DPR) dan Presiden. Panitia seleksi akan menyeleksi calon Dewan Komisioner Otoritas Jasa Keuangan dalam empat tahapan seleksi. Pertama, tahap administrasi. Kedua, tahap penilaian dari masyarakat, rekam jejak, dan makalah. Ketiga, tahap pemeriksaan kesehatan. Keempat, tahap wawancara. Setelah itu, panitia seleksi mengusulkan calon yang lolos seleksi kepada Presiden, lalu Presiden menyerahkannya kepada Dewan Perwakilan Rakyat untuk dilakukan fit and proper test.

Dapat dilihat bahwa independensi Otoritas Jasa Keuangan sebagaimana yang dimaksud dalam Pasal 1 Undang-Undang Nomor 21 Tahun 2011 tentang Otoritas Jasa Keuangan yang menyatakan bahwa Otoritas Jasa Keuangan terbebas dari campur tangan pemerintah tidak sepenuhnya benar. Hal ini yang menjadi indikasi bahwa adanya negosiasi politik pada saat pemilihan Dewan Komisioner Otoritas Jasa Keuangan.

Menurut Zainal Arifin Mochtar, independen berkaitan dengan beberapa hal. Pertama, independen yang berkaitan dengan pemberhentian anggota lembaga yang hanya dapat dilakukan bedasarkan sebab- 
sebab yang diatur oleh undang-undang pembentukan lembaga tersebut. Kedua, sifat dari independen itu sendiri bahwa pimpinan lembaga bersifat kolektif sehingga tidak berada di tangan satu orang sehingga berpengaruh dalam proses pengambilan keputusan di internal lembaga. Lalu, pimpinan lembaga tidak dikuasai oleh partai politik tertentu. Terakhir, masa jabatan pimpinan lembaga tidak habis secara bersamaan. ${ }^{3}$

Berdasarkan latar belakang masalah yang telah dijelaskan di atas, maka rumusan masalah yang dibahas dalam penelitian ini adalah sebagai bagaimana peran Otoritas Jasa Keuangan sebagai lembaga independen dalam melakukan pengawasan terhadap lembaga jasa keuangan di Indonesia? Dan apa saja kewenangan Otoritas Jasa Keuangan yang diatur dalam Undang-Undang Nomor 21 Tahun 2011 tentang Otoritas Jasa Keuangan?

\section{B. METODE PENELITIAN}

Penelitian hukum adalah suatu kegiatan ilmiah yang didasarkan pada metode, sistematika, dan pemikiran tertentu yang bertujuan untuk mempelajari satu atau beberapa gejala hukum tertentu dengan jalan menganalisanya. ${ }^{4}$ Penelitian ini bertujuan untuk memenuhi kebutuhan

3 Zainal Arifin Mochtar dan Iwan Satriawan, "Sistem Seleksi Komisioner State Auxiliary Bodies (Suatu Catatan Analisis Komparatif)", Jurnal Konstitusi, 2010, hlm. 152.

${ }^{4}$ Soerjono Seokanto, Pengantar Penelitian Hukum, (Jakarta: UI Press, 2007), hlm. 43. terhadap objek penulisan atas suatu karya ilmiah guna mendapatkan data-data, pokokpokok pikiran, serta pendapat lainnya dari pakar atau media apapun. Dalam hal ini, penulis memerlukan suatu metode yang berfungsi sebagai pedoman dalam pelaksanaan penelitian. Dalam pengumpulan bahan atau materi, penelitian ini didasarkan pada penelitian hukum normatif. Penelitian hukum normatif merupakan penelitian kepustakaan atau studi dokumen, yaitu penelitian yang dilakukan atau ditujukan pada peraturanperaturan tertulis yang disebut dengan data sekunder. ${ }^{5}$

\section{HASIL DAN PEMBAHASAN}

1. Peran Otoritas Jasa Keuangan sebagai Lembaga Independen dalam Melakukan Pengawasan terhadap Lembaga Jasa Keuangan di Indonesia

Pembentukan Otoritas Jasa Keuangan sebenarnya telah dicanangkan dalam Pasal 34 Undang-Undang Nomor 23 Tahun 1999 tentang Bank Indonesia. Namun, Otoritas Jasa Keuangan belum juga terbentuk walaupun telah diamanatkan bahwa Otoritas Jasa Keuangan harus dibentuk sebelum akhir tahun 2002. Kemudian Undang-Undang Nomor 3 Tahun 2004 tentang Perubahan atas Undang-Undang

\footnotetext{
5 Laurensius Arliman S., "Peranan Metodologi Penelitian Hukum dalam Perkembangan Ilmu Hukum di Indonesia", Jurnal Soumatera Law Review, Volume 1, Nomor 1, 2018, hlm. 50.
} 
Nomor 23 Tahun 1999 tentang Bank Indonesia mengamanatkan bahwa Otoritas Jasa Keuangan akan dibentuk selambatlambatnya 31 Desember 2010. Untuk mengakhiri permasalahan politik dan konflik kepentingan antara beberapa pihak yang mendukung maupun menentang pembentukan Otoritas Jasa Keuangan, pada tanggal 22 November 2011, rancangan Undang-Undang Otoritas Jasa Keuangan disahkan menjadi Undang-Undang Nomor 21 Tahun 2011 tentang Otoritas Jasa Keuangan. Lahirlah sebuah lembaga pengawas yang bersifat independen dalam menjalanan tugas yang kedudukannya berada di luar pemerintahan dan berkewajiban menyampaikan laporan kepada Badan Pemeriksa Keuangan (BPK) dan Dewan Perwakilan Rakyat.

Secara historis, pembentukan Otoritas Jasa Keuangan sebenarnya merupakan hasil kompromi untuk menghindari buntunya pembahasan Rancangan Undang-Undang Bank Indonesia oleh Dewan Perwakilan Rakyat. Pada masa pemerintahan Presiden B.J. Habibie, pemerintah mengajukan Rancangan Undang-Undang Bank Indonesia yang intinya memberikan independensi kepada bank sentral dan mengeluarkan fungsi pengawasan perbankan dari Bank Indonesia. Ide pemisahan fungsi pengawasan dari bank sentral tersebut dikemukakan oleh Helmut Schlesinger, mantan Gubernur Bundesbank (bank sentral Jerman) yang pada waktu penyusunan Rancangan Undang-Undang Bank Indonesia bertindak sebagai konsultan. Helmut Schlesinger mengambil pola bank sentral di Jerman yang tidak mengawasi bank. Pengawasan terhadap perbankan di Jerman dilakukan oleh suatu badan khusus yang bernama Bundesaufiscuhtsamt fur da Kreditwesen. Pada waktu konsep tersebut diajukan, muncul penolakan yang kuat dari kalangan Dewan Perwakilan Rakyat dan Bank Indonesia. Sebagai kompromi, maka disepakati bahwa lembaga yang akan menggantikan tugas Bank Indonesia dalam mengawasi bank juga bertugas mengawasi lembaga keuangan lainnya. Hal ini dimaksudkan agar tidak terlihat bahwa pemisahan fungsi pengawasan tersebut untuk memangkas kewenangan Bank Indonesia. ${ }^{6}$

Alasan dibentuknya Otoritas Jasa Keuangan antara lain karena semakin kompleks dan bervariasinya produk jasa keuangan serta dipengaruhi oleh globalisasi industri jasa keuangan. Di samping itu, alasan pembentukan Otoritas Jasa Keuangan karena pemerintah beranggapan bahwa Bank Indonesia sebagai bank sentral telah gagal dalam mengawasi sektor perbankan. Kegagalan tersebut dapat dilihat

\footnotetext{
6 Muhammad Djumhana, Hukum Perbankan di Indonesia, (Bandung: Citra Aditya bakti, 2012), hlm. 32 .
} 
pada saat terjadinya krisis ekonomi tahun 1997. Bukti nyata yang diakibatkannya antara lain yaitu dengan dibekukannya usaha 38 bank, antara lain Bank Ciputra, Bank Ganesha, Bank Pesona, Bank Alfa, Bank Aspac, dan lain sebagainya. Selanjutnya, ada 7 bank yang di-take over oleh pemerintah, yaitu Bank RSI, Bank Putera Sukapura, Bank POS, Bank Artha Pratama, Bank Nusa Nasional, Bank Jaya, dan Bank IFI. Selain itu, juga ada 4 bank pemerintah, yaitu Bank Dagang, Bank Exim, Bank Bumi Daya, dan Bapindo yang di-merger menjadi Bank Mandiri. ${ }^{7}$

Selain itu, dalam Penjelasan Umum Undang-Undang Nomor 21 Tahun 2011 tentang Otoritas Jasa Keuangan disebutkan bahwa pembentukan Otoritas Jasa Keuangan dimaksudkan agar dapat tercapai mekanisme koordinasi yang lebih efektif dalam menangani permasalahan jasa keuangan yang timbul dalam sistem keuangan sehingga lebih menjamin tercapainya stabilitas sistem keuangan.

Pengaturan dan pengawasan terhadap keseluruhan kegiatan jasa keuangan tersebut harus dilakukan secara terintegrasi. Hal ini sebagai akibat globalisasi pada sistem keuangan serta pesatnya kemajuan di bidang teknologi dan informasi serta inovasi finansial yang telah menciptakan

\footnotetext{
${ }^{7}$ Andrew Shandy Utama, "History and Development of Islamic Banking Regulations in the National Legal System of Indonesia", Jurnal Al-'Adalah, Volume 15, Nomor 1, 2018, hlm. 44-45.
}

sistem keuangan yang sangat kompleks, dinamis, dan saling terkait antara subsektor keuangan, baik dalam hal produk maupun kelembagaan. Adanya lembaga jasa keuangan yang memiliki hubungan kepemilikan di berbagai subsektor keuangan telah menambah kompleksitas transaksi dan interaksi antara lembaga jasa keuangan.

Otoritas Jasa Keuangan dibentuk dengan tujuan agar keseluruhan kegiatan di sektor jasa keuangan: terselenggara secara teratur, adil, transparan, dan akuntabel; mampu mewujudkan sistem keuangan yang tumbuh secara berkelanjutan dan stabil; mampu melindungi kepentingan konsumen dan masyarakat.

Adapun nilai strategis dari Otoritas Jasa Keuangan yang pertama adalah nilai integritas, dengan maksud bahwa Otoritas Jasa Keuangan bertindak objektif, adil, dan konsisten sesuai dengan kode etik dan kebijakan organisasi dengan menjunjung tinggi kejujuran dan komitmen. Kedua adalah nilai profesionalisme, dengan maksud bahwa Otoritas Jasa Keuangan bekerja dengan penuh tanggung jawab berdasarkan kompetensi yang tinggi untuk mencapai kinerja terbaik. Ketiga adalah nilai sinergi, dengan maksud bahwa Otoritas Jasa Keuangan berkolaborasi dengan seluruh pemangku kepentingan, baik internal maupun eksternal, secara produktif dan berkualitas. Keempat adalah 
nilai inklusif, dengan maksud bahwa Otoritas Jasa Keuangan terbuka dan menerima keberagaman pemangku kepentingan serta memperluas kesempatan dan akses masyarakat terhadap industri keuangan. Terakhir adalah nilai visioner, dengan maksud bahwa Otoritas Jasa Keuangan memiliki wawasan yang luas serta mampu melihat ke depan (forward looking) dan dapat berpikir di luar kebiasaan (out of the box thinking).

Dalam rangka mewujudkan perekonomian nasional yang mampu tumbuh secara stabil dan berkelanjutan, menciptakan kesempatan kerja yang luas dan seimbang di semua sektor perekonomian, serta memberikan kesejahteraan secara adil kepada seluruh rakyat Indonesia, maka program pembangunan ekonomi nasional harus dilaksanakan secara komprehensif dan mampu menggerakkan kegiatan perekonomian nasional yang memiliki jangkauan yang luas dan menyentuh ke seluruh sektor riil dari perekonomian masyarakat Indonesia. Program pembangunan ekonomi nasional juga harus dilaksanakan secara transparan dan akuntabel yang berpedoman pada prinsip demokrasi ekonomi sebagaimana yang diamanatkan oleh Pancasila dan UndangUndang Dasar Negara Republik Indonesia Tahun 1945. Untuk mencapai tujuan tersebut, program pembangunan ekonomi nasional perlu didukung oleh tata kelola pemerintahan yang baik yang secara terusmenerus melakukan reformasi terhadap setiap komponen dalam sistem perekonomian nasional. Salah satu komponen penting adalah sistem keuangan dan seluruh kegiatan jasa keuangan yang menjalankan fungsi intermediasi bagi berbagai kegiatan produktif.

Sebelum lahirnya Undang-Undang Nomor 21 Tahun 2011 tentang Otoritas Jasa Keuangan, pengawasan terhadap lembaga keuangan di Indonesia dilakukan oleh tiga institusi, yaitu Bank Indonesia, Badan Pengawas Pasar Modal dan Lembaga Keuangan, dan Kementerian Koperasi. Kementerian Koperasi bertugas mengawasi kegiatan koperasi. Badan Pengawas Pasar Modal dan Lembaga Keuangan bertugas mengawasi kegiatan pasar modal dan lembaga keuangan non bank. Bank Indonesia bertugas mengawasi perbankan yang mencakup bank umum, bank perkreditan rakyat, dan bank syariah. ${ }^{8}$

Dalam Pasal 34 Undang-Undang Nomor 3 Tahun 2004 tentang Perubahan atas Undang-Undang Nomor 23 Tahun 1999 tentang Bank Indonesia, pemerintah diamanatkan membentuk lembaga pengawas sektor jasa keuangan yang

\footnotetext{
8 Andrew Shandy Utama, "Independensi Pengawasan terhadap Bank Badan Usaha Milik Negara (BUMN) dalam Sistem Hukum Nasional di Indonesia", Jurnal Soumatera Law Review, Volume 1, Nomor 1, 2018, hlm. 17.
} 
independen selambat-lambatnya akhir tahun 2010, yang kemudian bernama Otoritas Jasa Keuangan. Otoritas Jasa Keuangan diberi tugas untuk mengawasi industri perbankan, asuransi, dana pensiun, pasar modal, modal ventura, perusahaan pembiayaan, serta lembaga jasa keuangan lainnya yang mengelola dana masyarakat.

\section{Kewenangan Otoritas Jasa}

Keuangan yang Diatur dalam Undang-Undang Nomor 21 Tahun 2011 tentang Otoritas Jasa Keuangan

Visi dari Otoritas Jasa Keuangan adalah menjadi lembaga pengawas industri jasa keuangan yang terpercaya, melindungi kepentingan konsumen dan masyarakat, serta mampu mewujudkan industri jasa keuangan menjadi pilar perekonomian nasional yang berdaya saing global dan dapat memajukan kesejahteraan umum. Terkait hal itu, maka misi yang disusun oleh Otoritas Jasa Keuangan yaitu sebagai berikut: mewujudkan terselenggaranya seluruh kegiatan di dalam sektor jasa keuangan secara teratur, adil, transparan, dan akuntabel; mewujudkan sistem keuangan yang tumbuh secara berkelanjutan dan stabil; melindungi kepentingan konsumen dan masyarakat.

Otoritas Jasa Keuangan melaksanakan tugas pengaturan dan pengawasan terhadap kegiatan jasa keuangan di sektor perbankan, sektor pasar modal, sektor perasuransian, sektor dana pensiun, sektor lembaga pembiayaan, dan sektor lembaga jasa keuangan lainnya. Dalam rangka melaksanakan tugas pengaturan, Otoritas Jasa Keuangan diberi kewenangan: menetapkan peraturan pelaksanaan UndangUndang Nomor 21 Tahun 2011 tentang Otoritas Jasa Keuangan; menetapkan peraturan perundang-undangan di sektor jasa keuangan; menetapkan peraturan dan keputusan Otoritas Jasa Keuangan; menetapkan peraturan mengenai pengawasan di sektor jasa keuangan; menetapkan kebijakan mengenai pelaksanaan tugas Otoritas Jasa Keuangan; menetapkan peraturan mengenai tata cara penetapan perintah tertulis terhadap lembaga jasa keuangan dan pihak tertentu; menetapkan peraturan mengenai tata cara penetapan pengelola statuter pada lembaga jasa keuangan; menetapkan struktur organisasi dan infrastruktur serta mengelola, memelihara, dan menatausahakan kekayaan dan kewajiban Otoritas Jasa Keuangan; menetapkan peraturan mengenai tata cara pengenaan sanksi sesuai dengan ketentuan peraturan perundang-undangan di sektor jasa keuangan.

Dalam rangka melaksanakan tugas pengawasan, Otoritas Jasa Keuangan diberi kewenangan: menetapkan kebijakan operasional pengawasan terhadap kegiatan jasa keuangan; mengawasi pelaksanaan 
tugas pengawasan yang dilaksanakan oleh Kepala Eksekutif Otoritas Jasa Keuangan; melakukan pengawasan, pemeriksaan, penyidikan, perlindungan konsumen, dan tindakan lain terhadap lembaga jasa keuangan, pelaku, dan/atau penunjang kegiatan jasa keuangan sebagaimana dimaksud dalam peraturan perundangundangan di sektor jasa keuangan; memberikan perintah tertulis kepada lembaga jasa keuangan dan/atau pihak tertentu; melakukan penunjukan pengelola statuter; Menetapkan penggunaan pengelola statuter; menetapkan sanksi administratif terhadap pihak yang melakukan pelanggaran terhadap peraturan perundangundangan di sektor jasa keuangan; memberikan dan/atau mencabut izin usaha, izin orang perseorangan, efektifnya pernyataan pendaftaran, surat tanda terdaftar, persetujuan melakukan kegiatan usaha, pengesahan, persetujuan atau penetapan pembubaran, serta penetapan lain sebagaimana dimaksud dalam peraturan perundang-undangan di sektor jasa keuangan.

Selain itu, dalam melaksanakan tugasnya, Otoritas Jasa Keuangan berkoordinasi dengan Bank Indonesia dalam membuat peraturan di bidang perbankan, yang mencakup kewajiban pemenuhan modal minimum bank; sistem informasi perbankan yang terpadu; kebijakan penerimaan dana dari luar negeri, penerimaan dana valuta asing, dan pinjaman komersial luar negeri; produk perbankan, transaksi derivatif, dan kegiatan usaha bank lainnya; penentuan institusi bank yang masuk katergori systemically important bank; serta data lain yang dikecualikan dari ketentuan tentang kerahasiaan informasi. ${ }^{9}$

Otoritas Jasa Keuangan dibentuk dengan tujuan agar keseluruhan kegiatan di sektor jasa keuangan terselenggara secara teratur, adil, transparan, dan akuntabel; mampu mewujudkan sistem keuangan yang tumbuh secara berkelanjutan dan stabil; serta mampu melindungi kepentingan konsumen dan masyarakat. ${ }^{10}$ Artinya, Otoritas Jasa Keuangan tidak hanya bertugas mengatur dan mengawasi sektor perbankan saja, tetapi juga menyelenggarakan sistem pengaturan dan pengawasan yang terintegrasi terhadap keseluruhan kegiatan di sektor jasa keuangan.

Berdasarkan Pasal 8 Undang-Undang Nomor 21 Tahun 2011 tentang Otoritas Jasa Keuangan diatur bahwa dalam rangka melaksanakan tugas pengaturan terhadap lembaga jasa keuangan, Otoritas Jasa

\footnotetext{
9 Hasnati, "Tanggung Jawab Direksi terhadap Terjadinya Kredit Macet pada Perbankan Berdasarkan Undang-Undang Nomor 40 Tahun 2007”, Jurnal Soumatera Law Review, Volume 2, Nomor 1, 2019, hlm. 87.

${ }^{10}$ Inosentius Samsul, "Perlindungan Konsumen Jasa Keuangan Pasca Pembentukan Otoritas Jasa Keuangan (OJK)", Jurnal Negara Hukum, Volume 4, Nomor 2, 2013, hlm. 25.
} 
Keuangan mempunyai wewenang: menetapkan peraturan pelaksanaan UndangUndang Nomor 21 Tahun 2011 tentang Otoritas Jasa Keuangan; menetapkan peraturan perundang-undangan di sektor jasa keuangan; menetapkan peraturan dan keputusan Otoritas Jasa Keuangan; menetapkan peraturan mengenai pengawasan di sektor jasa keuangan; menetapkan kebijakan mengenai pelaksanaan tugas Otoritas Jasa Keuangan; menetapkan peraturan mengenai tata cara penetapan perintah tertulis terhadap lembaga jasa keuangan dan pihak tertentu; menetapkan peraturan mengenai tata cara penetapan pengelola statuter pada lembaga jasa keuangan; menetapkan struktur organisasi dan infrastruktur serta mengelola, memelihara, dan menatausahakan kekayaan dan kewajiban Otoritas Jasa Keuangan; menetapkan peraturan mengenai tata cara pengenaan sanksi sesuai dengan ketentuan peraturan perundang-undangan di sektor jasa keuangan. $^{11}$

Berdasarkan Pasal 9 Undang-Undang Nomor 21 Tahun 2011 tentang Otoritas Jasa Keuangan diatur bahwa dalam rangka melaksanakan tugas pengawasan terhadap lembaga jasa keuangan, Otoritas Jasa Keuangan mempunyai wewenang: menetapkan kebijakan operasional

11 Jonker Sihombing, Otoritas Jasa Keuangan; Konsep, Regulasi dan Implementasi, (Jakarta: Ref Publisher, 2012), hlm. 33. pengawasan terhadap kegiatan jasa keuangan; mengawasi pelaksanaan tugas pengawasan yang dilaksanakan oleh Kepala Eksekutif Otoritas Jasa Keuangan; melakukan pengawasan, pemeriksaan, penyidikan, perlindungan konsumen, dan tindakan lain terhadap lembaga jasa keuangan, pelaku, dan/atau penunjang kegiatan jasa keuangan sebagaimana dimaksud dalam peraturan perundang-undangan di sektor jasa keuangan, memberikan perintah tertulis kepada lembaga jasa keuangan dan/atau pihak tertentu, melakukan penunjukan pengelola statuter, menetapkan penggunaan pengelola statuter, menetapkan sanksi administratif terhadap pihak yang melakukan pelanggaran terhadap peraturan perundang-undangan di sektor jasa keuangan; memberikan dan/atau mencabut izin usaha, izin orang perseorangan, efektifnya pernyataan pendaftaran, surat tanda terdaftar, persetujuan melakukan kegiatan usaha, pengesahan, persetujuan atau penetapan pembubaran, serta penetapan lain sebagaimana dimaksud dalam peraturan perundang-undangan di sektor jasa keuangan.

\section{PENUTUP}

Otoritas Jasa Keuangan adalah lembaga yang independen dan bebas dari campur tangan pihak lain, yang mempunyai fungsi, tugas, dan wewenang pengaturan, pengawasan, pemeriksaan, dan penyidikan terhadap lembaga jasa keuangan seperti 
perbankan. Dasar hukum dibentuknya Otoritas Jasa Keuangan adalah UndangUndang Nomor 21 Tahun 2011. Secara kelembagaan, Otoritas Jasa Keuangan berada di luar pemerintah, yang dimaknai bahwa Otoritas Jasa Keuangan tidak menjadi bagian dari kekuasaan pemerintah. Otoritas Jasa Keuangan dibentuk dengan tujuan agar keseluruhan kegiatan di dalam sektor jasa keuangan terselenggara secara teratur, adil, transparan, dan akuntabel;

\section{DAFTAR PUSTAKA}

Adrian Sutedi. Aspek Hukum Otoritas Jasa Keuangan. Jakarta: Raih Asa Sukses, 2014.

Andrew Shandy Utama. "History and Development of Islamic Banking Regulations in the National Legal System of Indonesia”. Jurnal Al'Adalah, Volume 15, Nomor 1, 2018. Hlm. 37-50.

"Independensi Pengawasan terhadap Bank Badan Usaha Milik Negara (BUMN) dalam Sistem Hukum Nasional di Indonesia". Jurnal Soumatera Law Review, Volume 1, Nomor 1, 2018. Hlm. 121.

. "Sejarah dan Perkembangan

Regulasi Mengenai Perbankan Syariah dalam Sistem Hukum Nasional di Indonesia". Jurnal Wawasan Yuridika, Volume 2, Nomor 2, 2018. Hlm. 100-113. . "Arah Kebijakan Pengawasan terhadap Perbankan Syariah dalam Sistem Perbankan Nasional di Indonesia". Jurnal Volksgeist, Volume 3, Nomor 1, 2020. Hlm. 4152.

Hasnati. "Tanggung Jawab Direksi terhadap Terjadinya Kredit Macet pada Perbankan Berdasarkan UndangUndang Nomor 40 Tahun 2007”. mampu mewujudkan sistem keuangan yang tumbuh secara berkelanjutan dan stabil; serta mampu melindungi kepentingan konsumen dan masyarakat. Otoritas Jasa Keuangan bertugas tidak hanya mengatur dan mengawasi perbankan saja, tetapi juga mencakup pasar modal, perasuransian, dana pensiun, lembaga pembiayaan, serta lembaga jasa keuangan lainnya.

Jurnal Soumatera Law Review, Volume 2, Nomor 1, 2019.

Hasnati, Sandra Dewi, dan Andrew Shandy Utama. "Perbandingan Prinsip Good Corporate Governance pada Bank Konvensional dan Bank Syariah dalam Sistem Hukum di Indonesia”. Jurnal Mizan, Volume 3, Nomor 2, 2019. Hlm. 197-207.

Imelda Tamba, Maria Florida Bunga Makin, dan Laurensius Arliman S. "Kualitas Pelayanan SDM Mempengaruhi Kepuasan Anggota Koperasi Simpan Pinjam Credit Union Jembatan Kasih Kp. Tanjung Uncang di Kota Batam". Jurnal Marketing, Volume 1, Nomor 1, 2018.

Inosentius Samsul. "Perlindungan Konsumen Jasa Keuangan Pasca Pembentukan Otoritas Jasa Keuangan (OJK)". Jurnal Negara Hukum, Volume 4, Nomor 2, 2013.

Jonker Sihombing. Otoritas Jasa Keuangan; Konsep, Regulasi dan Implementasi. Jakarta: Ref Publisher, 2012.

Laurensius Arliman S. Lembaga-lembaga Negara Independen (Dalam UndangUndang Dasar Negara Republik Indonesia Tahun 1945). Yogyakarta: Deepublish, 2016.

"Wacana Program

Pembangunan Nasional Semesta 
Berencana sebagai Landasan Pembangunan Negara

Berkelanjutan". Jurnal Manajemen Pembangunan, Volume 3, Nomor 3, 2016.

\begin{tabular}{|c|c|c|}
\hline \multicolumn{3}{|c|}{ "Peranan } \\
\hline Penelitian & Hukum & \\
\hline Perkemban & Ilmu & Hukum \\
\hline Indonesia". & . Jurnal Sou & umatera Lc \\
\hline Review, Vo & olume 1 , Nom & or 1,2018 . \\
\hline & Penegakan & ukum Bisı \\
\hline Ditinjau & dari & Idang-Unda \\
\hline Larangan & Praktik Mc & onopoli \\
\hline Persaingan & Usaha Tidak & k Sehat". I \\
\hline $\begin{array}{l}\text { Jurnalica, } \\
2019 .\end{array}$ & Volume 16 & , Nomor \\
\hline
\end{tabular}

Muhammad Djumhana. Hukum Perbankan di Indonesia. Bandung: Citra Aditya Bakti, 2012.

Ratih Agustin Wulandari. "Tata Kelola Perusahaan oleh Direksi PT BPR Dharma Nagari dalam Menerapakan Prinsip Good Corporate Governance".
Jurnal Soumatera Law Review, Volume 2, Nomor 2, 2019.

Sandra Dewi. "Mengenal Doktrin Dan Prinsip Piercing The Corporate Veil dalam Hukum Perusahaan". Jurnal Soumatera Law Review, Volume 1, Nomor 2, 2018.

Sandra Dewi dan Andrew Shandy Utama. "Pengawasan terhadap Perbankan Syariah oleh Otoritas Jasa Keuangan". Prosiding Seminar Nasional Aplikasi Sains dan Teknologi, 2018.

Wiwin Sri Haryani. "Independensi Otoritas Jasa Keuangan dalam Perspektif Undang-Undang Nomor 21 Tahun 2011 tentang Otoritas Jasa Keuangan". Jurnal Legislasi Indonesia, Volume 9, Nomor 3, 2012.

Zainal Arifin Mochtar dan Iwan Satriawan. "Sistem Seleksi Komisioner State Auxiliary Bodies (Suatu Catatan Analisis Komparatif)". Jurnal Konstitusi, 2010. 